\title{
LA REFORMA CONSTITUCIONAL EN EL PERL: IMPLICACIONES Y RETOS
}

Víctor García Toma

\section{Resumen}

En el presente artículo, el autor nos señala la posibilidad de una Reforma Constitucional como un medio para el cambio de la Constitución. Esta medida sólo será posible cuando el propio Poder Constituyente originario de manera expresa autorice al legislador ordinario a convertirse en recreador del orden constitucional. Finalmente, el autor indica que la inconstitucionalidad de la Reforma Constitucional se dará en la medida que el órgano facultado, en este caso el Tribunal Constitucional, transgreda los límites formales que son los requisitos de validez para la reforma, o, los limites materiales, los cuales se dirigen a conservar la esencia constitucional en el contenido de la Constitución.

\section{Summary}

In this article, the author points the possibitity of a Constitutional Reform as a way to change the Constilution. This measure will only he possible when the Constituent Power itself expressly authorizes the orcUnary legislature to become into a Creative ofthe constitutional order. Finally, the author indicales that the unconstitutionality of the Constitutional Reform will he given to the extent that the national authority, in this case the Constitutional Court, viólales the formal limits for the reform, or the material limits, which are aimed at preserving the constitutional essence the content ofthe Constilution.

\section{Sommaire}

Dans cet article, l'auteur souligne la possibil i té dime reforme constitutionnelle comme un moyen de changer la Constilution. Cette mesure ne sera pas possible lorsque le Pouvoir Constituant origine! lui-méme autorise expressément te législateur ordinaire á afin étre un récréative de l'ordre constitutionnelle. Enfin, l'auteur indique que Pinconstitutionnalité de la Reforme Constitutionnelle sera donnée dans la mesure oh l'autorité nationale, dans ce cas, la Cour Constitutionnelle, quand cette viole les limites formelles de validité sont les exigences poluta reforme, ou tes limites du matériel, le qui visent á préserver l'essence constitutionnelle du conteníi de la Constilution. 


\section{MARCO INTRODUCTORIO}

La Constitución es percibida como el instrumento político-jurídico que contiene un conjunto de valores, principios, normas y prácticas básicas destinadas a legitimar, modelar, organizar, regular e impulsar un tipo de sociedad política.

A trasluz, ésta determina la construcción jurídica de un orden político, formaliza el compromiso de alcanzar un tipo de coexistencia social y asegura el cabal goce de los derechos básicos de los miembros de una comunidad, para lo cual instituye limitaciones al ejercicio del poder.

La Constitución como expresión binaria de un derrotero histórico-político y marco de juridificación de las relaciones de poder, comprende un sistema de reparto de competencias, límites, vínculos y equilibrio institucional entre los distintos órganos de gobierno de un Estado. Por ende, instituye reglas y procedimientos que tienen simultáneamente como destinatarios a los gobernantes y gobernados. En dicho texto ocupa un espacio especial la defensa de la persona humana.

Según Giuseppe de Vergottini ${ }^{1}$ :

"(...) la Constitución está considerada como un sistema originario de normas jurídicas, sobre las cuales se basa la organización de los órganos constitucionales, el conjunto de sus competencias, el reconocimiento de la esfera jurídica del individuo, la relación entre autoridad pública y libertad individual

Desde una visión doctrinaria los contenidos de la Constitución pueden ser develados a la luz de los cinco aspectos siguientes:

a) La Constitución es un proyecto de vida

En un texto fundamental aparecen manifestados un conjunto de ideas, creencias y convicciones socialmente compartidas que apuntan a la construcción y consolidación de una forma política de convivir. Asimismo, implica un plan concertado para alcanzar determinadas metas vinculadas con el desarrollo societario y personal de un grupo humano adscrito a un espacio y un tiempo determinado.

En puridad, a través de la Constitución surge la voluntad concertada de los miembros de una comunidad política, los cuales ajustando sus intereses, expectativas y convicciones, asumen el reto de existir y coexistir conscientemente dentro de determinados principios, valores y formas de estructuración social, en pro de una futuridad común más plena y provechosa.

En ese sentido, tras el acto de transacción o conciliación que significa tener una Constitución, aparece un iceberg normativo que apunta a la transformación de la sociedad. Así, deviene en el suscitador de nuevas realidades; y opera como el incitador y el estimulante para que una sociedad en su conjunto levantándose sobre la resignada 
convalidación de un estado de cosas, apunte hacia la creación de "algo" nuevo y mejor para todos. Ergo, es el reflejo de las aspiraciones comunes de los integrantes de un Estado.

Al respecto, en el primer Plenario de la Asamblea Constituyente de 1978 su Presidente Víctor Raúl Haya de la Torre señaló lo siguiente:

" (...) Es obvio que la búsqueda de armonía y coincidencias que ofrezcan al texto constitucional un amplio consenso no significa, de modo alguno, el abandono de posiciones ideológicas ni de ideas, ni de programas (...) si queremos que la Constitución resulte válida para los más amplios sectores nacionales, debe concebirse como un documento que conjugue preceptos superiores y comunes (...) una Constitución no legisla para un partido ni para un sector, sino para todo el pueblo (...) debe ser guiada, además, por un sentido y una proyección de futuro. No legislamos para hoy ni para el inmediato mañana. La Constitución, si tenemos la sabiduría de concebirla realista y apropiadamente debe tener vigencia para varias generaciones $(\ldots)^{\prime \prime}$.

En ese sentido, la Constitución se asemeja a un histórico plan o programa de gobierno que refleja el sentimiento de una plural colectividad de personas en lo que respecta a su manera de ser, sentir y alcanzar prospectivamente.

En esa perspectiva presenta un conjunto de valores y principios éticos, políticos y jurídicos engarzados de manera coherente y conexa

\section{b) La Constitución es un estatuto de poder}

En un texto fundamental aparecen manifestados un conjunto de reglas destinadas a justificar y establecer una relación de mando y obediencia entre gobernantes y gobernados.

En ese sentido, aparece como el instrumento que formaliza la legitimación del ejercicio del poder y la de los entes institucionales encargados de entroncar la relación de subordinación razonada, en pro de alcanzar el comunitario proyecto de vida.

Ello conlleva a precisar los mecanismos y requisitos para alcanzar la calidad de gobernantes, sus competencias, responsabilidades y el tiempo de duración de dicha tarea.

Jorge Reynaldo Vanossi ${ }^{2}$ señala que la Constitución

"(...) es el enunciado institucional de las grandes 'reglas de juego' político y social que una comunidad adopta, para un cierto tiempo de su devenir histórico. por medio de un determinado reparto de competencias y con proyección u orientación hacia ciertos fines en los que la sociedad visualiza su porvenir

En ese orden de ideas, dichas reglas de juego representan el cause deseable por donde discurren los actores de una sociedad política: gobernantes y gobernados. 
En ese sentido el texto fundamental regula la capacidad de acción y medios concretos de coerción dentro del seno de una comunidad de personas. Así, el dominio, imperio, facultad y jurisdicción política queda sometida a las reglas de limitación y calibra miento por parte de los operadores estaduales. Ello, habida cuenta que corresponde a la Constitución precisar quien tiene competencia y atribución de mando; para que se le otorgue la atribución de disponer de qué manera habrá de ordenar; y hasta por cuánto tiempo tendrá la facultad de decidir.

c) La Constitución es una póliza de salvaguarda de los derechos fundamentales de la persona

En un texto constitucional aparece explicitado el reconocimiento y promoción de los derechos connaturales al ser humano por su sola condición de tal.

En ese aspecto, como bien señala Magdiel Gonzáles [Manual de derecho constitucional. Borrador en proceso de edición], la Constitución es un orden supremo que regula el ejercicio del poder político y que garantiza la vigencia y goce de los derechos fundamentales de la persona en una realidad social concreta.

Peter Haberle [El Estado constitucional. México: UNAM, 2001] expone que dicho contenido sugiere una concepción antropocéntrica. Así, el texto constitucional se "encuentra plenamente al servicio del ser humano, de su dignidad y libertad, e incluso igualdad (...)".

La necesidad del reconocimiento y protección constitucional se ampara en la necesidad intrínseca de toda comunidad política de conservar, desarrollar y perfeccionar al ser humano en el cumplimiento de sus fines de existencia e indefectible asociación con sus congéneres.

\section{d) La Constitución es un orden supremo constituyente de! sistema jurídico}

En un texto fundamental aparece la noción de fuente suprema dentro del ordenamiento jurídico de un Estado. Por ende, supone una normatividad supra encargada de consignar la regulación normativa básica de la cual emana la validez de todo el ordenamiento legal de una sociedad política; de aquí, que cree los órganos encargados de la producción normativa de las pautas de comportamiento constitucional; el señalamiento de las competencias materiales para legislar; la determinación de los procedimientos para la elaboración normativa; el establecimiento de los límites materiales para la elaboración normativa; y la imposición de los contenidos normativos.

En ese contexto, el resto de las normas imperativo-atributivas del Estado quedan sujetas a las reglas de respeto a la jerarquía y coherencia de contenidos con la Constitución.

En razón a lo expuesto, cabe afirmar que la Constitución es la norma fundamental y constitutiva de todo el orden jurídico.

Francisco Balaguer Callejón ${ }^{3}$ señala que:

"(...) en cuanto fuente suprema del ordenamiento no solo crea órganos, otorga competencias, determina procedimientos, sino también incluye límites 
materiales o impone contenidos obligados en la producción jurídica de los poderes constituidos (Ejecutivo, Legislativo, Judicial).

Como bien afirma Javier Pérez Royo [ob. cit.] "el mundo del derecho empieza en la Constitución (...) no existe ni puede existir jurídicamente una voluntad superior a la de la Constitución $(\ldots)^{\prime \prime}$.

Enrique Álvarez Conde [ob. cit.] señala que:

"(...) la Constitución es una especie de supe ley, de norma normarum, que ocupa el vértice de la pirámide normativa (...)".

Al ser situada en la cúspide o cima del ordenamiento estatal, conlleva a que las normas infraconstitucionales -leyes, decretos, resoluciones, etc. - sean tanto en lo formal como en lo sustancial, consistentes, congruentes y compatibles con ella, so pena de carecer de efecto legal alguno.

El texto fundamental deviene en la fuente de validez de todo el orden jurídico; amén de ser norma con fuerza normativa plenaria sobre los poderes constituidos y los particulares en relación específica a la producción de preceptos regulantes de la vida coexistencial.

En suma, la idea de Constitución como fuente del derecho implica considerar que sus enunciados expresan normas jurídicas supraordinantes y supremas. Estas son idóneas para abrogar o invalidar las normas precedentes a su vigencia o las posteriores afectas de incoherencia o incompatibilidad con ella.

El carácter vinculante de sus efectos no solo alcanza a regular la estructura, organización, fundamento y fines del cuerpo político; sino también las relaciones entre el Estado y los ciudadanos y la de estos entre sí.

e) La Constitución es la autorepresentación cultural de! pueblo de un Estado

En un texto constitucional aparece manifestado el conjunto de rasgos distintivos espirituales y materiales, intelectuales y afectivos que caracterizan un grupo social adscrito a un determinado escenario histórico de constitucionalidad.

Así, la inescindible relación telúrica que surge del medio ambiente y el grupo social que lo ocupa hace que la manifestación del arte, las letras, el medio de vida coexistencial, los sistemas de valores, las tradiciones, las convicciones patrióticas, tengan un cierto sello que distingue y diferencia a dicha colectividad política. De dicha relación surgen respuestas a la existencia y coexistencia social.

Los destinatarios de la Constitución dejan su impronta cultural; la cual fluye de una realidad histórica a veces singular o con matices distinguibles. Tal como señala Peter Haberle ${ }^{4}$ :

"(...) la Constitución no se limita a ser un conjunto de textos jurídicos o un mero compendio de reglas normativas, sino la expresión de un cierto grado 
de desarrollo cultural, un medio de auto representación propia de un pueblo, espejo de su legado cultural y fundamento de sus esperanzas y deseos

En esa perspectiva, cada pueblo asume para sí un conjunto de actitudes, creencias y valores; igualmente, asimila conocimientos en tomo al poder y expresa sentimientos de carácter político. Dicho conjunto es producto de un específico espacio tiempo-histórico.

En suma, la Constitución es la suma de orientaciones cognitivas, afectivas y valorativas de carácter político.

\subsection{La arquitectura de la Constitución de 1993}

Como bien afirma Francisco Fernández Segado $^{5}$ una primera lectura de la carta constitucional del Perú:

"(...) nos revela el influjo enorme que la Constitución de 1979 ha ejercido sobre ella $(\ldots)$ ".

Y es que la arquitectura constitucional de dicho texto de 1979 fue copiada casi literalmente.

Esta carta tenía el siguiente diseño:

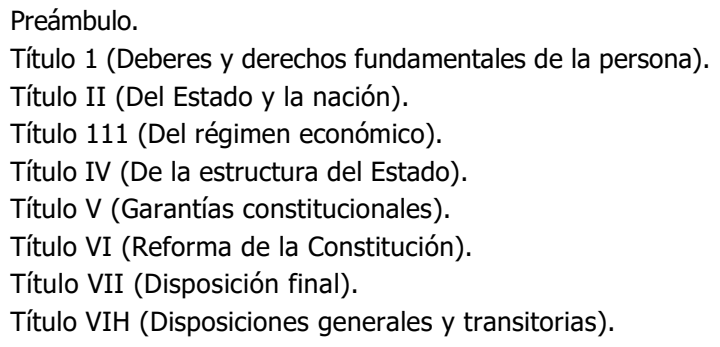

En la Constitución vigente se ha respetado dicho esquema, habiéndose eliminado únicamente el referido al Título Vil (Disposición final).

La citada omisión se refiere al artículo $307^{\circ}$ (Título VII), la que se entiende por sí misma, en razón a su contenido:

"(...) Esta Constitución (se refiere al texto de 1979) no pierde su vigencia ni deja de observarse por acto de fuerza o cuando fuere derogada por cualquier otro medio distinto del que ella misma dispone. En estas eventualidades todo ciudadano investido o no de autoridad tiene el deber de colaborar en el establecimiento de su efectiva vigencia.

Son juzgados, según esta misma Constitución y las leyes expedidas en conformidad con ella, los que aparecen responsables de los hechos señalados en 
la primera parte del párrafo anterior. Asimismo, los principales funcionarios de los gobiernos que se organicen subsecuentemente si no han contribuido a restablecer el imperio de esta Constitución.

El Congreso puede decretar, mediante acuerdo aprobado por la mayoría absoluta de sus miembros, la incautación de todo o de parte de los bienes de esas mismas personas y de quienes se hayan enriquecido al amparo de la usurpación para resarcir a la República de los perjuicios que se le hayan causado $(\ldots)^{\prime \prime}$.

De otro lado, se hace evidente que en su afán de aparecer como una Constitución "breve" el legislador constituyente procedió a ensamblar varios artículos del texto del 79 en uno solo.

Ahora bien, a casi veinte años de vigencia de la Constitución es claramente acreditable los profundos cambios introducidos en su texto fundamentalmente a partir de la reconstrucción del sistema democrático en el 2001. Así, a través de las leyes constitucionales dictadas por el Parlamento y las sentencias interpretativas del Tribunal Constitucional dicho texto ha adquirido una nueva identidad.

Al respecto, veamos lo siguiente:

Leyes Constitucionales:

- $\quad$ La Ley 26775 publicada el 24/04/97 modificó el artículo $2^{0}$ inc. 5 (derecho de rectificación).

- La Ley 28389 publicada el 17/11/2004 modificó el artículo $11^{0}$ (prestaciones de salud y pensiones).

- La Ley 28480 publicada el 30/03/2005 modificó el artículo $31^{0}$ (participación en asuntos públicos y derecho al voto).

- Ley 28480 publicada el 30/3/2005 modificó el artículo $34^{0}$ (derecho al voto de militares y policías).

- La Ley 28390 publicada el 07/11/2004 modificó el artículo 740 (principio de legalidad en materia tributaria).

- La Ley 26472 publicada el 13/06/95 modificó el artículo $77^{0}$ presupuesto del sector público).

La Ley 29041 publicada el 08/09/2009 modificó el artículo 80 (sustentación del presupuesto público).

- La Ley 29401 publicada el 05/04/2005 modificó el artículo 810 (Cuenta General de la República).

- $\quad$ La Ley 29402 publicada el 08/09/2009 modificó el artículo 870 (ahorro público).

La Ley 28607 publicada el 04/10/2005 modificó el artículo 90(Congreso: unicameralidad).

- La Ley 28484 publicada el 05/04/2005 modificó el artículo $92^{0}$ (función de congresistas e incompatibilidad con otros cargos). 
La Ley ํo 28484 publicada el 05/04/2005 modificó el artículo 96 (facultad de pedir informes a las dependencias públicas).

- La Ley 28484 publicada el 05/04/2005 modificó el artículo 103 (leyes especiales, retroactividad benigna, derogación de leyes).

- La Ley $N^{\circ} 28484$ publicada el 05/04/2005 modificó el artículo 107º (iniciativa legislativa).

- La Ley publicada el 17/11/ 2000 modificó el artículo $112^{\circ}$ (período del mandato presidencial y reelección).

- La Ley 27365 publicada el 05/11/2000 modificó el artículo $188^{\circ}$ (descentralización).

- La Ley 27680 publicada el 07/03/2002 modificó el artículo $191^{\circ}$ (descentralización).

- La Ley 28607 publicada el 04/10/2005 modificó el artículo $194^{\circ}$ (descentralización). La Ley 28607 publicada el 04/10/2005 modificó el artículo $200^{\circ}$ inc. 2 (garantías constitucionales).

La Ley 28607 publicada el 04/10/2005 modificó el artículo $200^{\circ}$ inc. 3 (garantías constitucionales).

La Ley 26470 publicada 12/06/1995 modificó la Primera Disposición Final (pensiones).

- La Ley 27365 publicada el 05/11/2000 modificó la Primera Disposición Transitoria Especial (Elección).

- La Ley 27600 publicada el 16/12/2000 dispuso suprimir la firma de Alberto Fujimori Fujimori del texto constitucional.

Sentencias interpretativas del Tribunal Constitucional

Caso Lucio Rosado Adanaque (Exp. 00895-2001-AA/TC) Reconocimiento de la objeción de conciencia.

- Caso Julio Salazar Monroe (Exp. 03100-2010-PHC/TC) Derecho al plazo razonable (derecho implícito).

- Caso Alfonso Baltazar Montalván (Exp. 01918-2002-HC/TC) Proscripción de la reformado in peus (derecho implícito).

Caso Genaro Villegas Namuche (Exp. 02488-2002-1IC/TC) Derecho a la verdad (derecho implícito).

- Caso Sindicato Universitario de Trabajadores de Telefónica (Exp. 011242001-AA/TC) Proscripción del despido sin causa justa.

- Caso Wilder Seijas Valderrama (Exp. 00206-2005-PA/TC) Protección contra el despido fraudulento. Caso Domitila Guzmán Castañeda (Exp. 00689-2003-AA/TC) Reconocimiento constitucional del principio de primacía de la realidad.

- Caso Congresistas de la República (Exp. 00030-2005-AI/TC) Conceptualización del Estado peruano como Democrático y Social de Derecho. 
- Caso Clever Nina Quispe Hernández (Exp. 00047-2004-AI/TC) Estructuración del ordenamiento jurídico nacional.

- Caso Roberto Nesta Brero (Exp. 00034-2004-AI/TC) Conceptualización del régimen económico.

- Caso Rosa Guerrero Guerrero (Exp. 03315-2006-AA/TC) Ampliación de los derechos constitucionales del consumidor.

- Caso Congresistas de la República (Exp. 00006-2003-AI/TC) Vacancia presidencial.

Caso Felipe Quispe Silva (Exp. 06167-2005-AA/TC) Jurisdicción arbitral.

- Caso José Crousillat López Torres (Exp. 03660-2010-PHC/TC) Derecho de gracia.

- Caso Defensor del Pueblo (Exp. 00017-2003-AI/TC) Delito de función.

- Caso Marcelino Tineo Silva (Exp. 00010-2002-A1/TC) Adecuación del sentido interpelativo del artículo $173^{\circ}$ de la Constitución a la Convención Americana de Derechos Humanos proscribiendo el juzgamiento de civiles en el fuero militar.

Finalmente, la presencia de las mutaciones constitucionales también ha tenido significación e importancia en la reconfiguración constitucional.

\section{LA NOCIÓN GENERAL DEL PODER CONSTITUYENTE}

Dicha noción fue primicialmente formulada por el abate Emmanuel Sieyés en su obra ¿Qué es el tercer Estado?

Consiste en la exposición primaria de la energía social de una comunidad, con el objeto de instituir una organización política y jurídica con vocación de perennidad, mediante la dación de un texto normativo fundamental denominado Constitución.

Dicha Constitución como expresión de un acto de instauración tiene la singularidad de no necesitar fundamentos de legitimidad en el Derecho. Por ende, como afirma Ricardo Guastini [Estudios de teoría constitucional. México; Coyoacán, 2001 ] tiene una justificación extra ordinem.

Dicho acto de instauración puede ser apreciado históricamente como fundacional o refundacional. En el primer caso, se plantea la creación de una comunidad política; en el segundo, se plantea que ante la aparición de nuevos actores políticos, económicos o sociales se produce un cambio de Constitución.

Dicho cambio -solo en aquellos estados que hubieren establecido expresamente procedimientos de reforma totales consecuencia de la aparición de nuevas fuerzas políticas, económicas o sociales. Ello implica un proceso de ruptura con la otrora Constitución vigente. De allí que la identidad y continuidad de esta sea negada por la elaboración y aprobación de otro texto constitucional.

El fenómeno revolucionario que conlleva una nueva estructuración políticosocial y una sustitución de los valores fundantes del ordenamiento institucional del "viejo" Estado, impone una nueva Constitución. 
Dicha fuerza o energía constitutiva o reconstitutiva de una comunidad política, representa como bien afirma Sergio Díaz Ricci [Teoría de la reforma constitucional. Buenos Aires: Ediar, 2004] la potencia generatriz de una Constitución; habida cuenta que dicho acto creador o recreador supone el establecimiento de un ordenamiento fundamental.

Emntanuel Sieyés señala que:

\section{"(...) Una Constitución supone ante todo un poder constituyente (...)".}

Néstor Pedro Sagüés [Teoría de la Constitución. Buenos Aires: Astrea, 2001] expone que la expresión poder constituyente alude tanto a la facultad para establecer una Constitución (poder-función) como al órgano ejerciente de esa facultad (poderpersona). De allí que plantee que en la práctica se habla tanto de "ser" como "tener" poder constituyente. Así, por ejemplo, en relación a un Congreso, Convención o Asamblea puede afirmarse que esta ejerce el poder constituyente; así como que ella misma es el poder constituyente.

A través del ejercicio de dicha facultad se crean o recrean los estados; y consecuentemente se formulan o reformulan las normas básicas que los cuerpos políticos requieren para el cabal ejercicio del poder político.

Los estados se crean en expresión de la libre determinación de los pueblos, lo que implica el derecho de estos a decidir auto determinativamente acerca de su condición política.

Los estados se recrean en expresión de la soberanía popular; es decir, como bien planteara Emmanuel Sieyés ${ }^{6}$ : "un pueblo siempre tiene el derecho de modificar su Constitución"; vale decir, a refundar su sociedad política.

Emst Bockenforde ${ }^{7}$ refiere que se trata de una fuerza y autoridad política capaz de crear, sustentar o cancelar una Constitución; por consiguiente es su fuente de creación. Asimismo, señala que dicho poder no es idéntico al que posee el Estado, ya que al de este lo precede y por cierto lo establece.

Javier Pérez Royo [Curso de derecho constitucional. Madrid: Marcial Pons, 2000] sostiene que una Constitución supone ante todo la presencia de un poder constituyente. Afirma que ambas nociones están unidas indisolublemente como "el creador a la criatura",

En ese sentido sostiene que el poder constituyente desde la lógica y la historia deviene en una necesidad para la existencia del Estado; y, por ende, también de la propia Constitución. Ambas no pueden ser pensadas racionalmente si no es a partir de esa facultad o potencia instauradora, fundadora o hacedora. 
El poder constituyente es el instrumento mediante el cual se decide la creación o recreación del cuerpo político y su Constitución. Este expone la presencia de un centro de energía institucionalizadora.

En efecto, se trata de una voluntad política dotada de la fuerza y energía suficiente capaz de establecer un modo y forma de existencia institucional; la cual se manifiesta a través de un orden normativo supremo denominado Constitución.

El poder constituyente originario se compone de elementos ontológicos y teleológicos. En el primer caso aparecen fundamentos que los integrantes del naciente o reconstituido Estado portan al gestarse dicho proceso; a saber: la cultura, los hábitos políticos, la actividad económica, etc. Con el segundo caso aparecen postulados que plantean el desiderátum o vocación pero siguen siendo o quieren ser un tipo de comunidad. Dicho poder es aquel que instituye el texto fundamental de la comunidad política; es decir, "arropa" su decisión política de fórmulas jurídicas. Dicha expresión de energía supone el origen mismo del poder; que por tal es previo al derecho, en la medida que este último no es más que un instrumento de convalidación y ordenación de aquel.

En ese orden de ideas, el sistema jurídico de un Estado es la expresión subsecuente del poder constituyente. Por ende, el legislador ordinario es impotente jurídicamente hablando para modelar relaciones coexistenciales contrarias al sentido directriz e inspirador de la obra constituyente. Este poder es originario cuando funda o refunda un Estado lo que se patentiza en la dación de una Constitución; y es derivado, instituido o reformador cuando enmienda el referido texto supra.

El proceso de creación, recreación o enmienda de las normas básicas del Estado se formaliza en la elaboración o reforma de la Constitución; lo cual se lleva a cabo por procedimientos distintos y más complejos que los que se realizan para la dación de la legislación ordinaria.

A manera de colofón de este apartado cabe señalar que Ricardo Guastini [ob. cit.] consigna que el Poder Constituyente Originario no sobrevive a la vigencia de su obra, ya que "desaparecen en ella y con ella".

\subsection{El poder constituyente originario $\mathrm{v}$ los poderes constituidos}

El poder constituyente originario es una facultad de acción que deriva del atributo prístino de una colectividad, de proveerse de manera autónoma una organización político-jurídica, a través del dictado de una Constitución. Representa la asociación de la voluntad con la fuerza, para adoptar una decisión, en conjunto, sobre el modo y forma de existencia política. Como expresa Jaime Araujo Rentería [Principios de derecho constituciona $\backslash$. Bogotá: McGraw-Hill, 1999], dicho poder no encuentra su razón de ser en el orden de cosas históricamente existentes, al que por el contrario impugna y ataca. A lo sumo puede fundamentarse en la libre determinación de los pueblos, la dignidad humana, la revolución, etc. Esta noción se justifica por sí misma; su potestad es pre o extra jurídica y suprema frente al derecho.

Jorge Reynaldo Vanossi [El poder constituyente. Buenos Aires: Depalma, 1976] califica este tiempo histórico como "etapa de la primigeniedad". 
Los poderes constituidos son aquellos creados por el poder constituyente; manifestándose, por tanto, dentro de la Constitución creada por esta.

Como bien refiere Carlos Sánchez Viamonte [ob. cit.], estos poderes nacidos y subordinados al poder constituyente -Ejecutivo, Legislativo y Judicial- constituyen el gobierno ordinario del Estado. Al respecto, Segundo Linares Quintana [Tratado de la ciencia del derecho constitucional argentino y comparado. Buenos Aires: Plus Ultra. 19771987] afirma que los poderes constituidos son creados por una Constitución que por tal los limita y regula; encontrándose, por consiguiente, en una jerarquía institucional inferior al del poder constituyente.

En suma, el poder constituyente originario es aquel que crea y organiza el Estado, en tanto que los poderes constituidos son los poderes organizados por aquel a efectos de asegurar su dirección y cumplimiento de los fines constitutivos. En esa perspectiva, la actuación de estos últimos debe concretarse dentro del marco de las limitaciones impuestas por el primero de los citados. Guillermo Calandrino ["Reforma constitucional". En: Curso de derecho constitucional. Buenos Aires: La Ley, 2001] expone que los poderes constituidos tienen como límites de su accionar aquellos que se derivan del cumplimiento de las pautas competenciales establecidas por el texto constitucional.

En lo genérico, la presencia de un poder constituido supone siempre una competencia, es decir, la facultad legal para realizar, otorgar o confirmar actos jurídicos. La naturaleza de ese poder, así como su extensión, la modalidad de su ejercicio, etc., se encuentran determinadas por una regla anterior, de modo tal que dicho poder se liga armoniosamente con el derecho. En cambio, en el caso del poder constituyente originario, a este se le aprecia con una inevitable potencia, fuerza o dominación de naturaleza política. La autoridad que posee o encierra es rebelde a una integración total dentro de un sistema jerárquico de normas y competencias. La distinción entre el poder constituyente originario y los poderes constituidos permite plantear las dos sustentaciones teóricas siguientes;

a) Los poderes que la Constitución crea y regenta -Ejecutivo, Legislativo y Judicial- se encuentran subordinadas a ella. Por ende, permite afirmar el principio de la supremacía de la Constitución.

b) La Constitución tiene validez incondicionada en virtud de proceder de quien tiene el poder de darla; el mismo que a su vez no se encuentra sometido a normas jurídicas preexistentes.

Tal autoridad entraña el ejercicio de la más alta manifestación del accionar político de una comunidad consciente de su personalidad histórica, y es la suprema expresión de la voluntad nacional premunida de idoneidad creadora para forjar un nuevo orden jurídico. Este poder se caracteriza por ostentar una prerrogativa superior, creativa, originaria y preexistente, respecto a los otros poderes conocidos doctrinariamente como constituidos (Legislativo, Ejecutivo y Judicial).

Esto es así porque el poder constituido solo actúa dentro de la esfera que le ha sido circunscrita por la labor del legislador constituyente. El marco constitucional solo puede ser modificado por aquel cuando el poder constituyente originario le asigna las competencias de un poder constituyente derivado. 


\section{EL PODER CONSTITUYENTE DERIVADO O CONSTITUIDO Y LA}

\section{REFORMA CONSTITUCIONAL}

Jaime Araujo Rentería [ob. cit.] afirma:

"(...) que el poder de reforma constitucional (...) formal es un poder integrado a un cuerpo que existe y obra gracias a la Constitución y que por lo mismo es un cuerpo constituido, no constituyente, delegado, no originario (...)".

Sostiene, que su legalidad y legitimidad deriva de la creación normativa del poder constituyente originario: la Constitución.

En efecto la autoridad del poder constituyente derivado se encuentra en la propia Constitución que reforma, en razón a que el texto supra expresamente se lo permite.

Desde una perspectiva histórica el poder constituyente derivado o constituido se gesta en 1791, con las diez primeras enmiendas establecidas en la Constitución americana (1787).

Jorge Reynaldo Vanossi [ob. cit.] señala que la noción de poder constituyente derivado pertenece en atención al tiempo histórico de su actuación, a la denominada "etapa de la continuidad". Su estudio corresponde exclusivamente al derecho, por ser típicamente un concepto de naturaleza jurídica.

Al respecto, Rubén Hernández Valle ${ }^{8}$ señala:

"(...) Cuando el poder constituyente se juridifica y se somete a los límites que él mismo establece en la Constitución para su ejercicio, se transforma en poder constituyente derivado $(\ldots)^{\prime \prime}$.

La presencia de un poder constituyente derivado o constituido supone siempre una competencia, es decir, la facultad legal para realizar, otorgar o confirmar actos jurídicos. La naturaleza, extensión, modalidades de su ejercicio, etc., se encuentran determinadas por una regla anterior, de modo tal que dicho poder queda "atado" al derecho.

En efecto, las normas de la Constitución expresan y limitan simultáneamente la capacidad reformadora asignada a los agentes políticos señalados para dicha tarea.

Este poder solo actúa dentro de la esfera que le ha sido circunscrita por el poder constituyente originario. Por ende, no instituye sino corrige o modifica.

\subsection{Los alcances del poder constituyente derivado}

La actividad del poder constituyente derivado o constituido se expresa en la reforma de la Constitución. La reforma constitucional se entiende como aquella facultad extraordinaria otorgada a un órgano estatal -usualmente el Parlamento-; la 
cual está destinada a promover la revisión y enmienda del texto fundamental establecido por el poder constituyente originario. Tal proceso se lleva a cabo con los textos constitucionales escritos y rígidos, e implica un conjunto de solemnidades que deben inexorablemente cumplirse a efectos de sustraer la revisión y enmienda normativa, del mecanismo común u ordinario de la legislación infraconstitucional.

Es evidente que mientras un texto constitucional en atención a su propia naturaleza normativa manifiesta una pretensión de perdurabilidad, la praxis política y la realidad social experimentarán cambios constantes. Como señala Luis Carlos Sáchica9

"(...) El poder de reforma tiende a la conservación de la Constitución mediante actualizaciones que captan el cambio en la realidad (...)".

En puridad, implica una técnica de defensa del texto fundamental contra los desajustes que sufre en su aplicación ante la concreta realidad espacio-temporal. Ella impide que las normas fundamentales queden reducidas a fórmulas sin proyección histórica.

En efecto, se trata de un mecanismo de articulación de la continuidad jurídica del cuerpo político; ello en razón a que a pesar de los cambios operados sobre la Constitución. esta mantiene su identidad, pero con la aspiración de robustecer su presencia, eficiencia y eficacia política. Al respecto, James Madison ${ }^{10}$ ha señalado que la reforma ha servido para proteger "por igual contra las facilidades que hacían a la Constitución demasiado variable y contra la perpetuación de sus manifiestos defectos".

Siendo la realidad política dinámica, esta exige que la Constitución se acople a dicho tráfago; con ello se asegura la continuidad jurídica del texto fundamental.

El poder de la reforma constitucional consiste en aquella actividad dirigida a modificar parcialmente una Constitución escrita y rígida, utilizándose para tal efecto un procedimiento especial jurídicamente preestablecido. Se trata de una competencia extraordinaria o excepcional, por cuanto se encuentra indicada por el propio ordenamiento constitucional (creado por el poder constituyente originario). Esta potestad derivada o constituida es la expresión de un orden ya existente, que se manifiesta mediante ciertos procedimientos de reforma constitucional contemplados en la ley básica del Estado.

La facultad de reforma o revisión solo puede considerarse como una forma propuesta, de obrar, al poder constituyente derivado; es decir, como una técnica oportuna, pero nunca como una regla inexorable. Es una verdad de Perogrullo que toda Constitución necesita recoger permanentemente los recados emanados de la vida social; para ello se ha creado la institución de la revisión orgánica. La reforma constitucional se encuentra ligada al proceso social, que, por tal, es siempre dinámico y cambiante. Esa relación entre norma y realidad es en muchos casos esquiva e inexistente; ya Vladimir Ilich Ulianov "Lenín", censuraba al lirismo jurídico sosteniendo 
que no debe olvidarse que "Ios hechos son más testarudos que la ley". El propio general Charles de Gaulle planteaba en sus memorias que "lo que está escrito, aunque sea sobre un pergamino, solo vale por su aplicación".

La revisión contiene una situación de aplicación del derecho por las vías del derecho mismo. Así, nace de la propia Constitución y, por tanto, está comprendida en la especie de las normas constitucionales, dado que se rige por una de ellas. Más aún, mediante dicho procedimiento la consagra y transforma en ley suprema. La revisión, como noción jurídica, es un aporte más del derecho constitucional norteamericano. Así, al influjo de hombres de la talla de Alexander Hamilton, James Madison y John Jay, se insertó en el artículo $V$ de la Constitución de 1787 la idea de que los cambios en su texto deberían producirse de manera especial y reflexiva, antes que por el súbito y violento paroxismo legislativo. Ellos esperaban (y acertaron) que las llamadas "enmiendas" preservaran al gobierno, de la excitación y turbulencia popular.

La aplicación de esta histórica concepción demuestra la vitalidad y lozanía permanente del texto fundamental de nuestros vecinos del norte. Ellas provienen de las veintisiete enmiendas efectuadas a lo largo de dos siglos, que son las que han permitido encontrar adaptabilidad a las condiciones sociales imperantes a lo largo de dicho tiempo.

La robustez de la Constitución americana no proviene del texto de 1787; ella es además de la interpretación jurisdiccional, la emanación de otra fuente que nosotros conocemos con el nombre de reforma. Este poder se mueve al interior del orden jurídico preexistente, opera dentro de una legalidad constitucional, y es oriundo de un derecho ya establecido. Su adecuación deviene de su validez y eficacia.

\subsection{Las características del poder constituyente derivado}

Entre las principales notas connotativas que presenta el poder constituyente derivado o constituido, como ente con capacidad de reformar el texto fundamental, aparecen las tres siguientes: la legitimación, la limitación y la eficacia.

Al respecto, veamos lo siguiente:

\section{a) La legitimación}

El accionar de dicho poder deriva de la misma Constitución que habrá de reformar. Esta es la base de su propia fundamentación y consentimiento político. Paolo Biscaretti di Ruffia [Derecho constitucional. Madrid: Tecnos, 1984] señala que se trata de una actitud normativa que se despliega sobre la del particular procedimiento establecido por la propia Constitución.
b)
La limitación

El accionar de dicho poder parte de presupuestos establecidos por el poder constituyente originario; es decir, se encuentra subordinado al orden establecido en cuanto a su actuación y alcances de su labor. 
Pedro de Vega García" señala que:

"(...) el poder de reforma, en la medida que aparece reglado y ordenado en la

Constitución se convierte en un poder limitado, lo que quiere decir que la actividad en revisión no puede ser entendida como una actividad soberana y libre

Dicha limitación establece la distancia que separa la acción legal de la acción revolucionaria. Esta última se expresa como una ruptura súbita y profunda que implica el desconocimiento de los otros fundamentos jurídicos hasta entonces existentes.

Gonzalo Ramírez Cleves [Límite de la reforma constitucional en Colombia. Bogotá: Universidad del Externado. 2005] expone que el poder reformador permite a través del cambio, el adecuar la norma básica a los tiempos y las necesidades de la sociedad; garantizando así su permanencia y estabilización política.

La doctrina establece que los límites que caracterizan al órgano reformador pueden ser formales y materiales. Los límites formales se refieren a la totalidad de requisitos objetivamente establecidos por la Constitución para que el proceso de reforma prospere, a saber:

- La determinación del órgano con competencia para ejercer la potestad modificatoria.

- El íter procedimental.

- La ratificación ciudadana del proceso de reforma (opcional).

Los límites materiales se refieren a algunos contenidos de la Constitución. Con ellos se indica la presencia de parámetros de identidad o esencia constitucional, inmunes a toda posibilidad de reforma. Dichos límites aseguran los supuestos ideológicos y valorativos en que descansa y asienta el sistema político.

c) La eficacia

El accionar de dicho poder tiene como fundamento el afirmar un vínculo armonioso entre el texto constitucional y la realidad política y social.

Siguiendo en parte a Pedro de Vega García [ob. cit.] consideramos que la reforma constitucional cumple las dos funciones siguientes:

- La posibilidad de reordenar las expresiones jurídicas a la dinámica realidad política y social de un Estado. Mediante ella se libra al texto fundamental de quedar reducida a una simple fórmula jurídica sin proyección histórica ni aplicación práctica. En esa hipótesis se entiende que la reforma constitucional no debe ser entendida como un instrumento de agresión sino de defensa de la Constitución, en la medida en que su accionar permite su pervivencia armónica con la realidad. 
- La posibilidad de llevar a cabo el proceso de adecuación sin quebrantamiento del sistema constitucional; sino más bien con el plácet y anuencia de este.

Para tal efecto, asume la tarea de adicionar, reducir, modificar o sustituir una parte de la Constitución por otra. Empero, sin que ello implique, en modo alguno, un acto de alteración, perturbación o subversión de la fórmula basilar que sustenta el orden constitucional.

La razonabilidad de la reforma constitucional se explica en razón a lo siguiente:

a) Por la constatación de una imperfecta acción constituyente originaria; es decir, por la existencia de omisiones, defectos o errores por parte del legislador constituyente en la elaboración del texto fundamental.

b) Por la presencia de cambios en la sociedad política; lo que implica el surgimiento de un "desfase" entre la norma y la voluble realidad.

\subsection{Los limites de la reforma constitucional}

El estudio de dichos límites pertenece simultáneamente a la ciencia política y al derecho. En el primer caso aparecen los topes que provienen básicamente de la realidad circundante, la conciencia del legislador o las convicciones de la comunidad. En este sentido Julio Cueto Rúa ${ }^{12}$ afirma que:

"(...) la más firme y sólida garantía de que una regulación constitucional repugnante a nuestros valores no se impondrá, está en el hombre mismo y no fuera de él, ya que normalmente el constituyente se sentirá apresado por vallas invisibles de las que no podrá escapar porque él no vive en un trasmundo, sino que participa necesariamente de las valoraciones ambientales: su existir es un coexistir con lo demás en el tiempo (...)".

Así pues, este proceso no puede consentir el absurdo, la irracionalidad y la asociabilidad, por lo que el poder constituyente reformador queda ligado al norte de la ética y la lógica. Los topes que actúan "sobre" el ejerciente del poder constituyente originario son los ideológicos, los estructurales, los axiológicos y los internacionales. Al respecto, veamos lo siguiente:

\section{a) Los topes ideológicos}

Hacen referencia a la percepción totalizadora de una concepción del mundo; es decir, a una cosmovisión de la existencia y coexistencia humana; amén del conjunto de creencias o valores que se ligan con una actitud de compromiso de comportamiento subjetivo e intersubjetivo.

12 CUETO RÚA, Julio Cueto. ¿Es posible declarar inconstitucional una reforma constitucional?

En: Justicia. Reproducción de la Revista La Ley, tomo 36. Argentina. Bolivia, Colegio de Abogados de Bolivia, 1993 
En efecto, la reforma queda "atrapada" en el sistema de creencias políticas vigentes. La asociación de ideas y convicciones con fuerza y proyección política son las de condicionar los objetivos de las modificaciones constitucionales.

En esa perspectiva nociones como justicia, libertad, igualdad, fraternidad, seguridad, paz, etc., dejan de ser meras indicaciones líricas para concretarse en guías para la actividad constituyente.

b) Los topes estructurales-institucionales

Hacen referencia a los ámbitos económico, social y político circundantes al proceso constituyente. En efecto, la reforma se generará adscrita a un modo de producción económica y una determinada configuración social, de donde emergen un conjunto de roles y pautas de comportamiento coexistencial. Por ende, operan sobre el legislador constituyente aspectos como la expresión de los agentes del capital y del trabajo, el arraigo religioso, la vocación influyente de los entes de la sociedad civil, etc.

En esa perspectiva el sistema económico-financiero, los grupos religiosos y sociales $\mathrm{u}$ otros factores reales de articulación social, exponen la gama de intereses y expectativas que orientan fácticamente la acción constituyente.

c) Los topes axiológicos

Hacen referencia al ámbito ético-político a que se contrae el ejerciente o ejercientes de dicho poder. Estos plantean el respeto a los valores asimilados por la comunidad.

Evidentemente, es inaceptable la consagración de la inmoralidad o amoralidad; así como, la vulneración de la dignidad humana, en razón de que dichas "acciones" romperían la finalidad sustentadora de las buenas prácticas de la comunidad.

d) Los topes internacionales

Hacen referencia a los condicionamientos fácticos que surgen de las acciones generadas por los estados y las organizaciones internacionales. Asimismo, incluye la visión interna de la política exterior y las relaciones internacionales. Al respecto, debe recordarse que en algunos casos se produce el acto creador de un impulso político externo; tal el caso del papel desempeñado por Inglaterra en relación a Canadá, Australia, Sudáfrica; o la Organización de las Naciones Unidas con relación a Kosovo o Bosnia-Herzegovina. Asimismo, no puede obviarse los condicionamientos que aparecen tras la formación de bloques políticos en el escenario internacional; o los vínculos o conflictos con los estados vecinos.

En el segundo caso aparecen los topes que provienen del derecho. Así, la atribución de la reforma es expresión de una competencia extraordinaria o excepcional, en el sentido de que puede modificar o redistribuir las demás competencias ordinarias del Estado. Al respecto, Cari Schmitt [Teoría de la Constitución. Madrid: Alianza Universitaria, 1970] señala que la competencia para reformar el texto fundamental no es una atribución normal, sino, más bien, una prerrogativa de carácter extraordinario y limitado. 
La facultad de reforma prescrita por una norma constitucional significa que una o varias reglas del texto fundamental pueden ser sustituidas, pero bajo el supuesto de que queden garantizadas la identidad y continuidad de la Constitución considerada como un "todo". Dicha facultad "O se explica por sí misma; la competencia para ejercerla no implica la utilización de una facultad usual (como dar leyes, conocer procesos judiciales, realizar actos administrativos), sino que se trata de una acción singular con límites y objetivos muy precisos.

En razón de lo expuesto, la potestad de enmendar contiene, pues, tan solo la atribución de practicar reformas, adiciones, refundiciones, supresiones, etc., pero con la restricción de mantener la fisonomía del texto. Para Cari Schmitt, la Constitución es intangible en aquello que es sustancial; en suma, la reforma de esta no acarrea su destrucción.

Mediante la reforma se puede modificar pero no roer la Constitución; en caso contrario, también se enerva su legitimidad como poder de revisión. Como tal, dicho tipo de poder promueve la "conservación" del texto magno mediante su permanente actualización con la realidad. La Constitución intenta ser la completa regulación jurídica del incesante y diverso proceso renovador de la vida de un Estado. De allí que se pueda, en cierto modo, comprender su relativa permanencia. Una Constitución perdurará en la medida que armonice con los procesos reales de coexistencialidad política; por ende, debe asumirlos y acomodarse a ellos. Los cambios formales la afectan, pero al integrarlos en su seno se renueva y así continúa viva y lozana. De lo contrario, cuando es desbordada por la realidad y es incapaz de "asumirla", se abre paso a la ingobernabilidad o a la dación de una nueva Constitución.

Es conveniente subrayar que la reforma tiene un carácter esencialmente integrador, en la medida en que intenta "acomodar" las normas a la realidad. El poder constituyente derivado es la potestad transformadora con sentido de reafirmación y continuidad. Sin embargo, para que esa dimensión integradora sea cabal existen límites que, en términos genéricos, conforman lo que podríamos denominar la fórmula basilar la cual no puede ser cambiada por la reforma constitucional. Contrario sensu, se abandona el cauce de la legitimidad constitucional y se origina un proceso revolucionario.

La existencia de estos límites es indispensable para el mantenimiento mismo de la Constitución, a efectos de que conserve su identidad pese a las modificaciones realizadas en su contenido. De manera que, aunque se hayan reformado partes íntegras, se mantendrá la continuidad de la misma Constitución en tanto se hayan respetado tales límites. La fórmula basilar de una Constitución se compone de un conjunto de principios éticos, políticos y jurídicos calificables de primordiales; ello implica la determinación de un techo ideológico, una forma de Estado, un sistema y forma de gobierno, un modelo económico, y por cierto de un catálogo de derechos fundamentales.

La fórmula basilar está dirigida a establecer con claridad cuatro aspectos; quién manda, cómo manda, bajo que pautas basilares y marco institucional manda y para qué manda en un determinado Estado. Ella es obra exclusiva del poder constituyente originario: su alteración configuraría una expresión revolucionaria, razón por la que queda fuera de la competencia del poder de reforma. La tarea, pues, del intérprete de la Constitución consiste en establecer dicha fórmula. Esta labor se simplifica extraordinariamente cuando puede ser contrastada de modo inmediato. Así, por ejemplo, el preámbulo de la Constitución de 1979 indubitablemente aclaraba esos aspectos.

A nuestro entender, la reforma total, que equivale al "cambio" de la Constitución 
no sería doctrinariamente posible desde el momento mismo en que la propia ley fundamental prevé su enmienda y corrección, pero no su sustitución. El poder constituyente originario es inalienable, no enajenable e intransferible, de lo que resulta que este no consiente que se le reemplace posteriormente en su titularidad primigenia.

Por ende, no puede admitir su propia destrucción o aniquilamiento, ni su aprobación por terceros.

Desde una perspectiva jurídica, el texto fundamental solo puede ser abolido en su totalidad, o en su fórmula basilar, mediante otro acto del poder constituyente originario o con expresa autorización de este. La facultad de reforma, prevista en una norma fundamental, no encuentra el privilegio de su cambio; por ello, la Constitución fuente del poder reformadorno nace, a su vez. del texto fundamental. Como señala Cari Schmitt [ob. cit.]:

"(...) Que una Constitución se dé a sí misma es un absurdo manifiesto (...)".

Como afirma Luis Carlos Sáchica ${ }^{13}$, quien está legitimado para reformar la Constitución tan solo puede:

"(...) conservar en lo esencial aquello que reforma, sin alterar ni sustituir su entidad propia, su sustancia. Podrá variar, modificar parcialmente la forma, suprimir lo adjetivo, adicionar lo necesario, rectificar lo contradictorio, pero siempre siguiendo los lineamientos, en trazos maestros que hacen de un ser lo que es $(\ldots)^{\prime \prime}$.

A guisa de ejemplo, Guillermo Calandrino [ob. cit.j expone que "el poder constituyente originario es aquel que establece los cimientos de una casa (techo, hormigón y columnas) en tanto que el poder constituyente derivado es aquel que se utiliza para modificar el orden con que recibimos una casa (anular una ventana, abrir una nueva puerta).

\subsection{El proceso de reforma constitucional como medio para el cambio de Constitución}

En atención a lo expuesto precedentemente la posibilidad de la dación de una nueva Constitución por la vía del proceso de reforma constitucional, solo es posible cuando el propio poder constituyente originario de manera expresa autoriza al legislador ordinario a convertirse en recreador del orden constitucional.

Al respecto, son citables los casos establecidos en las constituciones de Suiza, España. Paraguay, Austria. Argentina, Nicaragua, Uruguay, Venezuela, Cuba y Monaco.

\subsection{Los presupuestos doctrinarios para el proceso de reforma constitucional}

La reforma de la Constitución requiere, antes de ser llevada a cabo, el que de manera previa se observen algunos juicios de valor sobre su necesidad y oportunidad. 
las restricciones heterónomas y las reglas de aprobación. Al respecto, veamos lo siguiente:

a) La necesidad de la reforma

El legislador no puede descartar ni evitar al momento de discutir la probabilidad de una enmienda el tener que justificar las razones que exigen los cambios normativos. Tal necesidad se expresa desde las seis consideraciones siguientes:

La existencia de una grave crisis de legitimidad política.

La presencia excesiva de usos políticos o interpretaciones normativas constitucionales ocasionadas por el fenómeno de las mutaciones.

La subordinación de los preceptos constitucionales a las exigencias de quien depende la decisión política.

La existencia de contradicciones entre los mandatos de la Constitución y las exigencias sociales.

La inadaptación de las instituciones políticas previstas en la

Constitución.

La existencia de omisiones y vacíos normativos.

b) La oportunidad de la reforma constituciona

Alude a las circunstancias políticas adecuadas para llevar adelante el proceso de revisión constitucional. En este caso, el tiempo propicio es aquel en que existen las condiciones sociales y materiales, así como un clima de libertad y tranquilidad pública, que permitan a los ciudadanos y organizaciones políticas en general el manifestarse con pleno albedrío sobre el rubro.

En ese sentido, no son tiempos de reforma aquellos que coinciden con convulsiones políticas, guerra exterior, etc.

c) Las disposiciones intangibles

Son aquellas que tienen por finalidad librar radicalmente a determinadas normas constitucionales de cualquier tipo de modificación, lo cual quiere decir que existen preceptos que no son materia reformable. En efecto, ello implica un tope jurídico al objeto de la reforma.

Este tipo de disposiciones apoya lógicamente la imposibilidad de realizar una reforma total. Ellas son el resguardo de la legitimidad constitucional, ya que preservan los supuestos ideológicos y valorativos en que descansa el régimen político.

Este tipo de normas puede ser de dos clases:

c.I) Las disposiciones de intangibilidad articulada

Son las que se sustraen expresamente a cualquier enmienda, por medio de una concreta y directa prohibición constitucional.

La doctrina ha establecido que los textos constitucionales que las contienen, 
por lo general hacen referencia explícita a la inderogabilidad de la declaración de derechos, la división de los órganos del poder estatal, la irreversibilidad de la forma de gobierno, etc. Así, en la parte in fine del artículo $84^{\circ}$ de la Constitución francesa de 1958 se dispone:

"(...) La forma republicana de Gobierno no puede ser objeto de revisión

Una disposición análoga se encuentra en el artículo 139 de la Constitución italiana de 1947. En el ordenamiento constitucional peruano, las encontramos en el artículo $12^{\circ}$ de la Constitución de Cádiz (1812), que estableció que la religión de la Nación fuese perpetuamente la católica, apostólica y romana; y en el artículo $183^{\circ}$ de la Constitución de 1839, que fijó la inalterabilidad la forma de gobierno popular representativa fundada en la división e independencia de los poderes.

Más sugestivo aún fue el artículo $142^{\circ}$ de la Constitución de 1933, en donde textualmente se decía:

"(...) No hay reelección inmediata. Esta prohibición no puede ser reformada ni derogada $(\ldots)^{\prime \prime}$

c.2) Las disposiciones de intangibilidad implícita

Son las que permiten garantizar aquellos principios y valores primordiales de la Constitución, los mismos que no se encuentran expresados literalmente en ella, pues se trata de criterios sustantivos inmanentes e inherentes al propio texto.

La prohibición de reforma se genera a partir del espíritu o telos de la Constitución, sin que explícitamente aparezca una proclamación detallada en una pauta jurídica.

En puridad, afirman la existencia de límites innominados o tácitos. Se trata de impedir que el legislador constitucional transgreda las "fronteras" que le son impuestas por los principios y valores primordiales insertos en una Constitución. Estas disposiciones aparecen tras una labor deductiva de la fórmula basilar a cargo del órgano de control constitucional y hasta del propio órgano reformador. Expresan el encumbramiento normativo y la protección de los fundamentos éticos, políticos y jurídicos sobre los que se organiza el régimen político que proyecta la Constitución.

Al respecto, el Tribunal Constitucional alemán ha tomado para sí la corriente iusnaturalista, al haber reconocido una jerarquía o escala de valores en las normas fundamentales. Con ello ha puesto un tope inmanente y no articulado a la reforma constitucional en Alemania.

El hecho de que una Constitución no aluda expresamente a la existencia de cláusulas de intangibilidad articulada, en modo alguno significa la existencia de una facultad para la reforma total. Más bien, ello indicaría que el órgano legislador reformador y el de control de la constitucionalidad asumen de consuno la responsabilidad de señalar por vía objetiva la fórmula basilar de la Constitución; la que, por ende, no puede ser objeto de reforma.

Al respecto, el derecho comparado acredita que existen constituciones en 
donde el legislador constituyente ha declarado expresamente las zonas prohibidas de reforma; en tanto que en otras se ha establecido tácitamente que corresponde al legislador y al contralor constitucional "encontrar" la ubicación de dichas zonas. Esta demarcación se encuentra implícitamente inmersa en el seno mismo de la Constitución.

Como bien expone Roberto Rodríguez Gaona ${ }^{14}$ [ $£ 7$ control constitucional de la reforma a la Constitución. Madrid: Dykinson, 2006] existen ciertos contenidos que definen la obra de ingeniería constitucional forjada por el poder constituyente originario; estos devienen en los límites infranqueables al poder constituyente derivado. Así:

"(...) la Constitución posee partes que (...) en la praxis de la regularidad

jurídica no pueden alterarse o sustituirse, bajo pena de producir un cambio de Carta (...)".

William Marbury [The limitation upon the amending power. Harvard: Law Review, 1919-1920] sostiene que el poder de reforma tiene competencia para modificar la Constitución, lo que no posee es competencia para destruirla.

Ahora bien, la única forma posible de eliminar las cláusulas de intangibilidad es mediante la acción directa del poder constituyente originario. Al respecto, el Tribunal Constitucional en el caso Colegio de Abogados del Cusco (Exp. 00050-2004-PI/ TC) ha señalado claramente lo siguiente:

La inadmisibilidad jurídica de la afectación del contenido fundamental de la Constitución; vale decir, de su fórmula basilar. Por ende, la reforma "no puede destruir su fundamento ni su razón de ser".

La inadmisibilidad jurídica de la afectación de la fórmula basilar de la Constitución opera, aun cuando la Constitución no hubiese manifestado expresamente su "blindaje", ya que su modificación implicaría la destrucción de aquella.

En ese contexto, es dable señalar que siguiendo a Ignacio de Otto [ob. cit.] consideramos que el poder constituyente derivado no puede autoreformarse. Es decir, que la norma que confiere un poder de reforma no puede servir de fundamento para el establecimiento de un precepto modificador del proceso de enmienda.

Para tal efecto, debe recordarse que los alcances de dicha norma no son aplicables a ella misma. De allí que aun cuando una Constitución pueda ser objeto de una reforma en razón de existir un precepto que la permita y regule, en cambio este último no se encuentra expuesto a la posibilidad de ser reformado siguiendo el íter procedimental establecido por sí mismo.

c) Las restricciones heterónomas

Son aquellas que derivan de normas jurídicas ajenas a la Constitución. En puridad, son externas al derecho nacional, aunque este las admite, recibe e incorpora. Así. tenemos el caso de los tratados de paz, los procesos de integración regional y los acuerdos de guerra, en cuyas cláusulas existe el consentimiento del Estado de las condiciones fijadas en aquellos. 
Al respecto, el artículo $27^{\circ}$ de la Convención de Viena sobre los Tratados, consigna que el Estado no puede desligarse de sus compromisos internacionales argumentando la existencia de normas de derecho interno, salvo cuando estos fueron celebrados con violación manifiesta de las reglas estaduales de competencia para su aprobación y/o ratificación.

En ese contexto, Néstor Pedro Sagüés [ob. cit.] es concluyente cuando afirma que "un poder constituyente posfundacional no libera al Estado de sus compromisos internacionales preexistentes".

Un ejemplo de lo expuesto aparece en el artículo $4^{\circ}$ inc. 2 de la Convención Americana sobre Derechos Humanos de la cual nuestro país es suscriptor, en donde se establece lo siguiente:

"(...) En los países que no han abolido la pena de muerte esta solo podrá imponerse por los delitos más graves, en cumplimiento de sentencia ejecutoriada del tribunal competente y de conformidad con una ley que establezca tal pena, dictada con anterioridad a la comisión del delito. Tampoco se extenderá su aplicación a delitos a los cuales no se aplique actualmente $(\ldots)^{\prime \prime}$.

En esa perspectiva, ante el eventual conflicto entre una norma convencional (Tratado) y una norma interna en donde esta permite el incumplimiento de la primera, esta queda resuelto mediante la aplicación del principio de convencionalidad.

Dicha aplicación opera en dos planos: la jurisdicción supranacional o la jurisdicción interna. En el primer caso, aparece un órgano supranacional reconocido en sus competencias por el propio Estado; el cual tiene como objetivo valorar el grado de cumplimiento de las obligaciones convencionales, a partir de la concordancia y armonía entre la conducta estadual y la prescripción jurídica internacional.

Al respecto, es citable el caso Olmedo Bustos y otros (vs. Chile) en donde al amparo de la Constitución de dicho Estado se prohibió la exhibición de la película La ultima tentación de Cristo. Es del caso que la Corte Interamericana estableció que la censura cinematográfica se encuentra proscrita por la Convención Americana de Derechos Humanos; por lo que ordenó su exhibición y determinó la armonización del texto constitucional con las obligaciones internacionales.

Asimismo, es invocable el caso Ricardo Boyce y otros contra Barbados (2007), en donde la Corte Interamericana de Derechos Humanos resolvió conmutar la pena de muerte aplicada en contra de uno de los justiciables de conformidad con la legislación interna; lo cual implicaba una infracción de la Convención Americana de Derechos Humanos; y de la que el citado cuerpo político es suscribiente.

En el segundo caso, aparece un órgano jurisdiccional interno, el cual tiene por reconocido mandato de un ente supranacional, el garantizar la primacía de una obligación convencional.

Al respecto, es citable el caso Trabajadores Cesados del Congreso vs. Perú (2006) en donde se estableció que el principio de convencionalidad:

"(...) es el control que pueden y deben ejercer los órganos de la justicia nacional respecto a actos de autoridad entre ellos, normas de alcance general, conforme a las atribuciones que le confieren los ordenamientos a los que se hallan sujetos y las disposiciones del derecho internacional de los derechos 
humanos, a los que se encuentran vinculados por diversos actos de carácter soberano -ratificación o adhesión a un tratado, reconocimiento de una competencialos estados a los que corresponden los órganos nacionales(...)

De lo expuesto, se colige los límites de una reforma constitucional frente a la normatividad internacional previamente reconocida por el propio Estado.

d) Las reglas de aprobación

Son aquellas que permiten certificar la conclusión del proceso de obra constituyente.

El derecho comparado presenta alguna de las consideraciones siguientes;

Exigencia de una mayoría calificada para la aprobación de las reformas. Exigencia de una doble aprobación distanciada en el tiempo.

Exigencia de un referéndum confirmativo.

\subsection{La inconstitucionalidad de la reforma constitucional}

En concordancia con lo expuesto en el rubro sobre los límites del poder constituyente derivado, consideramos que la reforma constitucional no puede afectar la fisonomía o identidad de la Constitución. Ello en razón a que a diferencia del Poder Constituyente Originario que es plenipotenciario, en cambio el Parlamento como órgano constituyente derivado es condicionado.

En ese sentido, en el caso Reforma Constitucional del Régimen Pensionario (Exp. 00050-2004-PI\%TC y acumulados) el Tribunal Constitucional se declaró competente para ejercer el control de constitucionalidad sobre una ley de reforma, acotando que se encuentra habilitado conforme lo dispone el inciso 4 del artículo 200 de la Constitución.

Asimismo, en el caso Colegio de Abogados de lea (Exp. 0014-2002-A1\%TC) señaló que;

"(...) el poder de reforma de la Constitución, por muy especial y singular que sea su condición, no deja de ser un auténtico poder constituido y, por lo tanto limitado (...)".

Más aún, dicho colegiado estableció que le corresponde velar porque la norma suprema no sea en sí misma vulnerada a través de normas modificatorias que puedan atentar, tanto contra los principios jurídicos y valores democráticos como sobre los procedimientos establecidos para una reforma constitucional.

Asimismo, consignó que los límites que caracterizan al órgano reformador son los siguientes:

a) Límites formales 
Estos se encuentran referidos a los requisitos objetivamente reconocidos por la Constitución para otorgar validez a la reforma. Entre estos aparecen el órgano investido con la capacidad para ejercer la potestad enmendadora y el íter legislativo.

b) Límites materiales

Estos se encuentran referidos a los contenidos de la Constitución: es decir, implican el resguardo de los parámetros de identidad o esencia constitucional, inmunes a toda posibilidad de reforma. Entre estos aparecen las disposiciones de intangibilidad articulada y las disposiciones de intangibilidad implícita. El primer caso de control de la reforma de la Constitución se produjo en los Estados Unidos de América, a través del caso Hollingsworth vs. Virginia (1798), en donde se declaró que la undécima enmienda era conforme a la Constitución.

Esta enmienda había sido objetada por una supuesta infracción formal consistente en no haber sido aprobada por el Presidente de la República en los términos del artículo I, sección 7 de la Constitución.

Posteriormente han existido pronunciamientos en los casos Hawke vs. Smith (enmienda decimoctava, 1920) y Leser vs. Garret (enmienda decimonovena, 1922).

La Corte Suprema de la India en el caso Indira Gandhi vs. Shi Ray Narain, anuló una enmienda constitucional (1976); y en el caso Minerva Mills vs. Union of India, impidió la modificación de la fórmula de revisión de la Constitución (1980).

En Colombia, es citable el caso Carlos Moreno Novoa y Alvaro Echeverri Uruburu contra el Acto Legislativo $N^{\circ}$ 2. Allí, la Corte Suprema en 1978, declaró la inconstitucionalidad de la convocatoria del Congreso de la República, a una Asamblea Constituyente por vicio de forma. Posteriormente, la Corte Constitucional entre 1992 y el 2003 establecerá un control a los límites formales. Luego accederá al control sobre los límites materiales, tal y conforme aparece de lo resuelto en el caso reelección presidencial inmediata (2006). En suma, el control opera sobre límites formales y materiales.

En la Argentina, la Corte Suprema admitió a trámite el control de la constitucionalidad de la reforma contenida en el artículo $14^{\circ}$, bis, relativa al derecho de huelga. Así, en el caso Soria de Guerrero vs. Bodegas y Viñedos Pulenta Hermanos S.A. (1963) resolvió que:

"(...) la intervención de esta Corte es pertinente para decidir (...), si el artículo $14^{\circ}$ nuevo de la Constitución nacional fue sancionado de conformidad con las normas del reglamento interno dictado por la Convención Constituyente de $1957(\ldots)$ ". Es decir, "acerca de la falta de concurrencia de los requisitos mínimos e indispensables que condicionan la creación de una ley".

En el caso Carlos Santiago Fayt vs. Estado Nacional (1995), anuló una norma emanada de la reforma constitucional de 1994, concerniente a la fijación de un plazo (el cumplimiento de setenta y cinco años de edad) para la estabilidad de los jueces federales. Dicha modificación fue declarada inconexa e incompatible en relación a lo 
dispuesto en la Ley 24309 (Ley de Convocatoria a Reforma Constitucional).

En nuestro país, el Tribunal Constitucional ha tenido oportunidad de pronunciarse en el caso Reforma Constitucional del Régimen Pensionario (Exp. 00050 - 2004-AI/TC y acumulados) en donde declaró fundada en parte la demanda de inconstitucionalidad contra la Ley 28449; y en el caso Miguel Ángel Mufarech Nemy (Exp. 0024-2005-PI/TC) en donde declaró constitucional la reforma de los artículos $91^{\circ}, 191^{\circ}$ y $194^{\circ}$ del texto fundamental de la República. Al respecto, puede señalarse que el Tribunal Constitucional ha reconocido la existencia de límites formales y materiales.

\subsection{El proceso de reforma y el sentimiento constitucional}

Toda enmienda constitucional emprendida por razones oportunistas, para facilitar una gestión política, puede contribuir a una depredación del sentimiento constitucional o significar una traba para el enraizamiento definitivo de este en el corazón del pueblo. Esta debe promoverse con la anuencia o adhesión de la ciudadanía, y no solo ser fruto de una mayoría parlamentaria interesada en viabilizar un mejor manejo del gobierno, ni servir para satisfacer los particulares intereses políticos del gobernante de tumo. Es aceptable que se exponga que no se ha dado todavía el caso de un cuerpo político que haya colapsado por causa de una Constitución incompleta o necesitada de reforma, pero muchos regímenes han fracasado por el excesivo poder del grupo político que detentaba el poder.

Es más fácil vivir con una Constitución con lagunas, que con una que se ha convertido en la "pelota de juego" de quienes detentan el poder. Finalmente, consideramos que toda participación popular en el proceso de reforma -cualquiera fuere su modalidad técnicaes una contribución a la educación cívica y un elemento de integración política. Una nación vivirá democráticamente tan solo cuando le esté permitido comportarse democráticamente. Como lección de la historia han quedado registradas las palabras expresadas por el ex dictador boliviano Mariano Melgarejo (gobierno de 1864 a 1871) quien ante el Parlamento de su país señaló lo siguiente:

"(...) Sepa el señor diputado (...) que la Constitución de 1861, que era muy buena, me la metí en este bolsillo; y la de 1868, que. según estos doctores es mucho mejor, ya me la metí en este otro $(\ldots)^{\prime \prime}$.

En principio la Constitución es un trozo de papel lleno de grafías, es un "cuerpo de letras inerte" que solo por el sentimiento y voluntad de los gobernantes y gobernados se hace carne, hueso y espíritu; es decir, cobra vida.

\subsection{Los alcances de la "constitucionalización" de la reforma total (cambio) de la Constitución}

El Tribunal Constitucional en el caso Colegio de Abogados de lea (Exp. 000142002-AI/TC) en donde se impugnó la validez constitucional de la Ley 27600 la cual tenía por objeto llevar a cabo una reforma total de la Constitución, confirmó jurisdiccionalmente que el Poder Legislativo -como expresión de un poder derivado o constituido- carece de facultad alguna para llevar a cabo, una reforma total amparado 
en lo dispuesto en el artículo $206^{\circ}$ del texto supra; vale decir, que pudiese modificar la fórmula basilar o aprobar la redacción de una nueva Constitución.

En esa línea, ha establecido que las actividades del Poder Constituyente Originario jurídicamente solo pueden llevarse a cabo de las maneras siguientes:

a) Por medio de una Asamblea oCongreso Constituyente.

b) Por medio de un Referéndum.

En esta última hipótesis el supremo intérprete ha recordado que de conformidad con lo dispuesto en el artículo $32^{\circ}$ inc. 1 de la Constitución, puede realizarse un referéndum para llevar a cabo una reforma total; es decir, que esta es admisible

siempre que en ella participe directamente el pueblo como instancia decisoria. En efecto, el artículo $39^{\circ}$ de la Ley 26300 -Ley de los Derechos de Participación y Control Ciudadano- establece que dicho proceso puede ser viabilizado por la ciudadanía a través de este mecanismo y bajo un procedimiento también ad hoc.

De lo expuesto por el Tribunal Constitucional aparece lo siguiente:

a) El artículo $32^{\circ}$ de la Constitución reconoce la existencia de una función constituyente. Ello implica la autorización para instaurar un nuevo orden constitucional a través de un referéndum. Al respecto, Pedro de Vega [ob. cit.] señala que el referéndum es una expresión de garantía en pro de la aplicación de un dogma de la teología política popular, según el cual: "vox populi, vox dei".

b) El Poder Legislativo, en cuanto poder derivado o constituido no puede ejercer la función constituyente originaria, por consiguiente se encuentra indubitablemente impedido de cambiar la fórmula basilar o aprobar una nueva Constitución.

c) El Poder Legislativo como órgano constituido depositario de la representación de la voluntad nacional, puede proponerle a la ciudadanía un proyecto de Constitución. En efecto:

"(...) la elaboración (...) en sede parlamentaria, necesaria e inexorablemente debe concluir con su sometimiento a referéndum, so pena de declararse la inconstitucionalidad de dicho proceso (...)".

Esto debe configurarse con sujeción al Reglamento del Congreso.

d) Decisión en vía de participación directa a través de un referéndum, por parte de la ciudadanía. En ese sentido, expone que:

"(...) al analizarse la introducción de los mecanismos de democracia directa y, entre ellos la del referéndum, se concordó (tácitamente) en la absoluta necesidad que en el supuesto de reforma total de la Constitución, tuviera que participar el pueblo directamente. Ello en atención a la trascendencia que tiene el acto de instaurar un nuevo orden constitucional (...)". [Congreso Constituyente Democrático. Diario de Debates del 
Congreso Constituyente Democrático. Pleno de 1993. Tomo 3, Lima, 1993, pág. 2010-2020],

Ahora bien, el Tribunal Constitucional en cuanto a la prohibición expuesta en el segundo párrafo del artículo $32^{\circ}$ de la Constitución, ha señalado que esta solo opera para los casos de reforma parcial; es decir, los realizados conforme al artículo $206^{\circ}$ de la Constitución, Así, el impedimento a someter a referéndum las normas de carácter tributario o presupuestal, o los tratados internacionales en vigor, está dirigido a que dicha modificación solo se produzca mediante la mayoría parlamentaria ultra calificada (dos tercios) exigido por el texto supra.

\section{LA REFORMA CONSTITUCIONAL NO FORMAL}

Karl Loewenstein [Teoría de la Constitución. Barcelona; Ariel, 1984] señala que la Constitución ideal sería aquella en que el orden conformador del proceso político y el desarrollo futuro de la comunidad (político, social, económico, cultural) pudiese ser previsto de tal manera que no fuese necesario un cambio en las normas. Sin embargo, es inevitable que la Constitución no pueda prever totalmente el derrotero de lo venidero.

La Constitución es un organismo "vivo", siempre en movimiento, como la vida misma y sometida a la dinámica de la realidad. De esta última se develan procedimientos no formales que cambian el contenido de un texto fundamental. No se trata aquí de justificar estos procedimientos, sino tan solo de explicarlos: ellos cumplen la función de adecuación entre la realidad normativa y la realidad histórico-política.

Ahora bien, la doctrina reconoce que la reforma constitucional formal es aquella que atiende a la modificación del texto básico mediante un acto normativo y con estricta observ ancia del procedimiento que la propia Constitución señala. Por tal motivo, toda reforma que se genere al margen de estos supuestos debe ser considerada como no formal.

La realidad y verdad incontrastable de la vida de los pueblos demuestra que aquello que en principio se presenta como improcedente y reñido con la supremacía del texto fundamental, se consuma como un hecho excepcional que integra un conjunto de posibilidades de reforma, que no necesariamente carece de legitimidad. Más aún. existen casos notorios y evidentes en donde se han desarrollado funciones propias del poder reformador con mayor efectividad.

Las manifestaciones de reforma constitucional no formal son dos: la mutación constitucional y la norma de habilitación constitucional.

\subsection{La mutación constitucional}

Dicha noción alude al cambio de significado o sentido de la Constitución sin que ello implique la alteración de su expresión escrita.

Sergio Díaz Ricci [ob. cit.] expone que se trata de:

"(...) aquel fenómeno normativo en que un precepto normativo sufre una 
modificación de su contenido significativo sin que se haya alterado su expresión literal

En puridad, surge una alteración semántica -cambio de significado del signo lingüístico- para adecuar el "sentido" de la norma constitucional a la realidad.

Como afirma Georg Jellinek [Teoría general del Estado. Buenos Aires: Albatros, 1954], se trata de prácticas políticas, usos constitucionales e interpretaciones judiciales contrarias al sentido de los términos o alcances de las cláusulas, con alteración de su contenido intrínseco y primicial o de su significación originaria, como imagen de la evolución.

La mutación constitucional es una expresión doctrinaria surgida del publicismo alemán de fines del s. XIX y principios del s. XX. Al respecto, debe señalarse que la creación de la Constitución del Imperio alemán de 1871 es la consecuencia de muchos previos intentos de unificación.

Como bien refiere Ana Victoria Sánchez Urrutia ${ }^{15}$ :

"(...) La Unión Alemana estaba compuesta por estados muy distintos entre sí; desde los grandes ducados como Mecklemburgo-Schwein donde existía el absolutismo, hasta las Ilamadas ciudades libres, como Habsburgo, que eran repúblicas, pasando por monarquías limitadas como la prusiana (...)".

El referido ordenamiento se superpuso a confederaciones anteriores y al régimen organizativo de cada uno de los estados miembros; lo que generó una suerte de inadaptación formal de los ordenamientos particulares al ordenamiento imperial. Dicho factor motivó a que juristas de la talla de Georg Jellinek y Paul Laband [Cfr. Humberto Enríquez Franco. Derecho constitucional. Trujillo: Editora FECAT, 1999] estudiaran el fenómeno de las mutaciones constitucionales. Así, el citado Laband describirá como la Constitución del Reich se transformó sin que se accionen los mecanismos de reforma constitucional.

El proceso de mutación no implica necesariamente falseamiento del orden constitucional, más sí discontinuidad o insuficiencia del ordenamiento para responder a los imperativos de las fuerzas vitales que presionan sobre la decisión política. La mutación constitucional alude a un fenómeno que se produce en aquellos estados cuyas constituciones escritas, sin someterse a la reforma formal adquieren un sentido nuevo, por la vía de la interpretación, un contenido distinto o incluso llegan a perder vigencia por un uso contrario. Dicho proceso no necesariamente se realiza de manera consciente.

En ese sentido, la mutación constitucional es "hija" del no uso o imposibilidad de ejercicio del mecanismo de reforma constitucional.

Se trata de una transformación en la realidad del poder político, de la estructura social o del equilibrio de intereses, sin que dicho proceso quede actualizado en 
el documento constitucional. Estos "cambios" no son necesariamente conscientes o deliberados. A través de la mutación se plantea una operación que no tiene por finalidad modificar el texto de la Constitución, sino cambiar el significado o contenido que se atribuye al mismo. En consecuencia, la función tanto de la reforma constitucional como de la mutación será la de adecuar la realidad normativa constitucional con la realidad histórico-política.

Es evidente que la mutación carece de todo sentido allí donde las reformas se realizan con relativa frecuencia. Inversamente, ella se produce cuando la extrema rigidez y complejidad son características del procedimiento de reforma, 0 ante la miopía

- incuria del legislador. Una aspiración del legislador constituyente, al momento de dictar el texto base, consiste en promover una relación armoniosa entre la realidad y la normatividad. Empero cuando la realidad no encaja en la práctica jurídica o sufre notorias variaciones, ella señalará la necesidad de cambios por un imperativo histórico; esto no puede ser de otra manera, ya que ambos conceptos (realidad y normatividad) implican una mutua adaptabilidad y correlatividad. El cambio se legitima bajo la forma de una "necesidad política"; es decir, en aras de que la Constitución responda a las necesidades vitales del Estado.

La mutación se produce por una acción u omisión funcional de algún órgano u organismo constitucional; o por una conducta ciudadana repetida y reiterada que termina siendo avalada por algún órgano u organismo constitucional.

En suma, la mutación es obra del acto interpretativo, la práctica institucional - el hecho político.

\subsubsection{Los supuestos de la mutación constitucional}

Le corresponde el mérito al jurista chino Hsü Dan Lin -como estudioso del constitucionalismo alemán de la República de Weimar (1919-1933)- el haber formulado una serie de consideraciones sobre los supuestos de la mutación constitucional. Para dicho autor la mutación constitucional implica una incongruencia entre las normas constitucionales y la realidad.

Partiendo de la doble naturaleza de la Constitución en sentido formal y en sentido material, Hsü Dan Lin divide las mutaciones de la siguiente manera: La mutación formal y la mutación material. La mutación formal se produce como consecuencia del divorcio entre el derecho constitucional gramaticalmente establecido y el efectivamente y realmente "vivido". La mutación material se produce cuando se desarrollan relaciones jurídieo-políticas en la realidad vital del cuerpo estadual que están en contradicción con el sistema encamado en la Constitución. siguientes:

Ahora bien, ambas situaciones producen las cuatro modalidades de mutación

a) Mutación por medio de la práctica estatal no violatoria de la Constitución

Se trata de prácticas practer legetn que regulan situaciones jurídieo-políticas no previstas en las prescripciones constitucionales. Hacen referencia a las "adiciones" no legisladas, generadas por los operadores de la Constitución. 
En puridad, plantea la incorporación de un contenido nuevo a la Constitución material.Tal el caso de la efectuada por la judicatura norteamericana a raíz del fallo del juez John Marshall en el caso Madison vs. Marbury en 1803. Aquí se cubrió una laguna legal en relación a la asignación de competencias para examinar el control de constitucionalidad de las leyes. En esa misma orientación, aparecen en Argentina los casos Ángel Siri (] 957) y Samuel Kot S.R.L. (1958), que originaron la creación de la acción de amparo

c) Mutación por la no ejercibilidad de determinadas competencias o atribuciones constitucionales

Se trata de potestades constitucionales discrecionales o programáticas; las que por causas sobrevinientes y el transcurso del tiempo, caen en desuso. Tal como esgrime Ricardo Guastini [ob. cit.] esta es fruto de un problema de "actuación constitucional". lo que genera que la Constitución quede "inactuada" en el tiempo.

En puridad surgen ante la imposibilidad del ejercicio por razones de facticidad política o por el "congelamiento" en el texto de las competencias y atribuciones establecidas en la Constitución.

Tal el caso francés de 1873, en donde la Convención Constituyente eligió al promonárquico Mac Mahon como primer Presidente de la III República. Este al encontrar problemas para gobernar con una cámara de mayoría republicana, la disuelve conforme a la Ley Constitucional de fecha 25 de febrero de 1875.

Curiosamente, Mac Mahon se verá obligado a dimitir cuando la facción republicana vuelva a ganar las elecciones parlamentarias.

Mac Mahon es reemplazado por Jules Grevy, un republicano partidario de la reducción de los poderes presidenciales, el cual se abstendrá de ejercitar las facultades presidenciales de vetar las leyes o disolver el Parlamento.

Esta actitud será conocida como la "posición Grevy" en virtud de la cual ningún otro presidente durante la III República (1871-1944) ejercitara la competencia de disolución.

En el constitucionalismo peruano es citable el caso de la Constitución de 1933, en donde se consignó la creación de un Consejo Nacional de Economía y un Senado Funcional. Durante la vigencia de dicho texto jamás se implementaron los referidos órganos. Asimismo, aparece el caso del artículo $152^{\circ}$ de la Constitución vigente que prescribe la elección popular de los jueces de paz. Añádase a lo expuesto, su objetiva presencia en los casos de derechos programáticos sin desarrollo en el tiempo.

d) Mutación por medio de una práctica contraria a la Constitución

Se trata de prácticas contra legem; que por tales devienen en opuestas a los preceptos constitucionales. Estas afectan la eficacia más no la validez de la Constitución. En este tipo de mutación se expone la imposición de lo ficticio sobre lo normativo. Pedro de Vega García [ob. cit.] expone que surgen "cuando la contraposición entre facticidad y normatividad es evidente". Ello da lugar a la imposición de la fuerza de los hechos sobre la fuerza coercitiva de las normas. 
Tal el caso del artículo $93^{\circ}$ de la Constitución, en donde a pesar de haberse establecido que los congresistas no se encuentran sujetos a mandato imperativo ni a forma alguna de interpelación; en la praxis estos reciben presiones y consignas de sus organizaciones políticas.

e) Mutación por medio de la interpretación constitucional

Se trata de la asignación de significados a las normas constitucionales de conformidad con las cambiantes concepciones y necesidades de las épocas y sin atención al sentido literal de la Constitución o a la voluntad del legislador constituyente. En puridad, conllevan la modificación prístina -ya sea objetiva o subjetivamente- del texto fundamental. Tal el caso de la cambiante interpretación constitucional de los jueces de la Corte Suprema de los Estados Unidos en relación a temas de los derechos civiles de los negros.

Debe advertirse que no cabe hablar de mutación creada por actos normativos; en este aspecto, la expedición de una norma contraria a la norma fundamental no genera una mutación, sino simplemente un supuesto de inconstitucionalidad. Ello en razón de que las mutaciones actúan dentro de la realidad y de la práctica política, más no dentro de la labor legislativa. En suma, como bien expone Alberto Villacorta Michelena i Los limites del poder constituyente. Lima: Grijley, 2003] la mutación solo actúa dentro del campo de la realidad y de la práctica política y no dentro de la normatividad.

En el Perú, este proceso puede verificarse en el caso de la interpretación constitucional del valor de los decretos leyes. Es evidente que, a pesar de su inconstitucionalidad formal -en actuación a lo dispuesto en el artículo 46 del texto supra-, ellos rigen por imperio de los hechos. La realidad social reconoce que estas normas generan en muchos casos efectos irreversibles y ponen en juego la seguridad jurídica. En efecto, ello ha sido expresado por el propio Tribunal Constitucional en el caso Marcelino Tineo Silva (Exp. 0010-2002-AI/TC).

Pedro de Vega García [ob. cit.] expone que entre la mutación y la reforma constitucional existe una relación "complementaria y excluyente". Así, en tanto exista un Estado con vocación normativamente actualizante la mutación carecerá de sentido.

Ahora bien, el límite de la mutación aparece cuando la confrontación entre realidad y normatividad es tan grande y abierta que el concepto de supremacía constitucional queda subordinado a las meras interpretaciones prácticas o usos políticos. Allí queda "sentenciada" la Constitución a su perención fáctica.

\subsection{La norma de habilitación constitucional}

Este concepto es una derivación de los criterios planteados por la escuela vienesa de Kelsen en tomo a la validez y vigencia de las normas. Se encuentra vinculado con el estudio de los problemas que se derivan de la aplicación de los alcances de la pirámide jurídica: por ende, de los conflictos de significación opuesta o contradictoria, entre pautas legales de jerarquía distinta.

Como es sabido, la relación fundamental entre los contenidos normativos consiste en que la significación de un precepto de grado inferior no puede rebasar los 
"límites" que le impone la de mayor rango, ya que de lo contrario carecería de valor. En virtud de ello, como sanción a dicho rebasamiento surge la nulidad de la norma por inconstitucional. Así se desprende tácitamente, por ejemplo, del artículo $51^{\circ}$ de nuestro texto fundamental, el cual afirma:

"(...) La Constitución prevalece sobre toda norma legal; la ley, sobre las normas de inferior jerarquía, y así sucesivamente $(\ldots)^{\prime \prime}$.

Sin embargo, puede acontecer que no se aplique la consecuencia sancionadora prevista -o sea, su expulsión del ordenamiento jurídico-, sino que, por el contrario, se concrete en la realidad la determinación de equivalencia entre las normas en conflicto, de manera tal que el deber o derecho asignado en exceso no carecerá de validez jurídica. Lo expuesto se produciría por "gracia" de la norma de habilitación, que iguala a ambas normas dejando de lado la sanción anuladora. Dicho suceso se ampararía en la mera existencia de un hecho extemo a la propia pirámide jurídica. Al respecto, Fritz Schereier [Conceptos y formas fundamentales de! derecho. Citado por Carlos Santiago Niño. Introducción al análisis del derecho. Buenos Aires: Losada, 1942] esgrime el siguiente enunciado sustentatorio:

"(...) Si un hecho de postulación de grado inferior rebasa los límites que le señala la significación de grado superior, deben producirse las consecuencias establecidas para las normas nulas. Pero mediante un rodeo a través de la norma de habilitación, el precepto nulo queda incluido en el derecho positivo correspondiente y se transforma en un precepto válido (...)".

Ahora bien, en lo específico y atinente al derecho constitucional la presencia de una norma de habilitación se concreta debido a alguna de las tres razones siguientes:

a) Inexistencia de un sistema jurisdiccional de control y defensa de la constitucionalidad. En este caso, al no existir un órgano contralor, la norma inconstitucional queda habilitada para seguir perteneciendo al ordenamiento institucional.

b) Inexistencia de un recurso para cuestionar la inconstitucionalidad de una norma. En este caso, al no existir medio alguno que consagre la nulidad de la norma inconstitucional, esta queda automáticamente habilitada.

c) Existencia de una resolución judicial expedida por algún órgano contralor de la constitucionalidad que, por error, convalida la norma infractoria de la Constitución. En este caso, la autoridad de la cosa juzgada de dicha resolución, promueve la modificación de la norma supra, aunque el juez constitucional hubiere infringido el principio de supremacía normativa al dar por válida una norma incoherente y contradictoria a su texto.

Jorge Reynaldo Vanossi [ob. cit.] sostiene que la habilitación constitucional proviene de la inexistencia o falta de control eficaz de constitucionalidad que anule el vicio o el exceso legislativo, quedando este, por tanto, convalidado. Nosotros agrega- 
mos que, en los hechos, determina la modificación del contenido del corpus constitucional. De allí que la norma de habilitación que "confirma" la validez y eficacia de una decisión política o jurisdiccional presuntamente incompatible con la Constitución, puede ser tácita o expresa.

La norma de habilitación es tácita por la inexistencia de control constitucional. La norma de habilitación es expresa cuando a pesar de haberse utilizado los mecanismos de control, por un objetivo error de interpretación plasmado en una resolución jurisdiccional, no se inaplica ni se declara la inconstitucionalidad de la decisión. En este caso, la conclusión de un proceso bajo la regla de la cosa juzgada determina la validez de dicha decisión; y por ende, la informal reforma de la Constitución. En suma, cuando la errática sentencia queda ejecutoriada, lo inválido queda habilitado a ser considerado como válido.

Como afirma Sebastián Ariusta [Derecho constitucional. San José: Ediciones Aguila, 1997], esta norma de habilitación constitucional traduce al lenguaje normativo el principio medieval: "error principis just Paci" (el error de principio se convierte en derecho). Así la norma de habilitación constitucional es consecuencia de un gazapo en el razonamiento jurisdiccional. En esa perspectiva, la justicia constitucional permite o ejecuta la norma inconstitucional.

Por su parte, Germán Bidart Campos ${ }^{16}$ afirma que la norma de habilitación constitucional se genera como consecuencia de:

"(...) un fenómeno propio de la dinámica constitucional (...) que revela la movilidad constante y las vicisitudes del mundo jurídico $(. . .)^{\prime \prime}$.

De allí que dicha situación "informal" tenga que ser "formalizada" admitiéndose la enmienda producida por un error de interpretación.

En puridad, la norma habilitante es consecuencia de una actividad jurisdiccional omisiva, inhibitoria o convalidante.

La confirmación de constitucionalidad de una norma inconstitucional perpetra que ante la imposibilidad de impugnar una resolución que ha adquirido el carácter de cosa juzgada, devenga en una reforma irregular "promovida" por el órgano de control constitucional.

La doctrina explica que la aceptación jurisdiccional de un montaje argumentativo desnaturalizante, la interpretación aislada de una cláusula constitucional, la utilización inadecuada de la analogía, el uso inapropiado de los principios jurídicos, etc. Son factores que explican el error interpretativo de un órgano de control.

Con juicio "benigno" podemos señalar que la Resolución 2191-99-JNF. de fecha 31 de diciembre de 1999 expedida por el Jurado Nacional de Elecciones, configura un caso de habilitación constitucional; habida cuenta que declaró improcedente las tachas ciudadanas interpuestas contra la tercera candidatura presidencial de Alberto Fujimori Fujimori; quien como consecuencia de ello quedó hábil para postular como candidato al cargo de Presidente de la República a pesar que el artículo $112^{\circ}$ de la Constitución de 1993 y la Resolución 172-94 emitida por el propio Jurado Nacional de Elecciones se lo impedía. 
En resumen, la norma habilitante es "supuesta" en los casos de inexistencia de un sistema o medio procesal de control de la constitucionalidad o es "real" en los casos de pronunciamientos jurisdiccionales erráticos.

\section{EL FRAUDE CONSTITUCIONAL}

Dicho concepto alude a la utilización espuria del procedimiento de reforma. Así. desde la "legalidad" se destruye el orden constitucional.

Tal el caso de Gustavo Adolfo Hitler quien cumpliendo la fórmula revisora prevista en la Constitución de Weimar, implemento un régimen nazi. Así. tras el provocado siniestro del edificio del Parlamento alemán por parte del propio gobierno, Hitler consiguió el 26 de febrero de 1933 la aprobación del denominado "Decreto del Incendio"; con el cual consiguió abolir la libertad de prensa, el derecho a la libre expresión, el derecho a la privacidad de las comunicaciones, el respeto a la propiedad privada y la usurpación de funciones de los gobiernos regionales.

Posteriormente el 23 de mayo de 1933. Hitler consiguió la aprobación de la denominada "Ley Habilitante", mediante la cual se le delegó las funciones del Parlamento por un período de cuatro años.

En suma, sobre dicha base legal obtenida de conformidad con la Constitución de Weimar, Alemania dejaba de ser una República Democrática para pasar a una Dictadura.

Finalmente, mediante la denominada "Ley de Disolución" de fecha 31 de enero de 1934 quedó abrogada la Constitución de Weimar, se declaró al Estado alemán nacionalsocialista y con régimen de partido único; ello se realizó sin que se hubiese producido un quebrantamiento formal de la legalidad.

Como expresa Pedro de Vega [ob. cit.]:

"(...) se llegó de este modo a la singular paradoja de la destrucción total de un sistema constitucional desde el ejercicio de su propia legalidad (...)".

\section{LA RESPONSABILIDAD POR EOS ACTOS DEL}

\section{PODER CONSTTTUYENTE}

En relación a la obligación o exoneración de responsabilidad por los daños y perjuicios que ocasiona el poder constituyente al actuar ya sea en una actividad refundadora o reformadora, la doctrina ha establecido dos posiciones radicalmente opuestas. La primera postula el principio de continuidad jurídica que acepta la invariabilidad de la obligación estatal de reparar los daños y perjuicios que ocasiona dicha actividad pública. Por consiguiente, el cuerpo político se encuentra constreñido a observar el deber indemnizatorio por la afectación de derechos obtenidos al amparo de la Constitución sustituida o reformada. Tal el caso de las personas perjudicadas por la supresión de alguna magistratura pública. La segunda postula el principio de discontinuidad jurídica que considera que al no existir solución de continuidad entre las obligaciones del Estado y el recreado o reformado, por consiguiente, no se reconoce obligación alguna sobre los daños y perjuicios que se pudieren causar tácticamente. 
En puridad señala no existir una precedente fuente creadora de un derecho objeto de resarcimiento.

Jorge Reynaldo Vanossi [ob. cit.] expone que en el caso concreto del poder constituyente originario no cabe imputar obligación reparadora al Estado, por cuanto tal poder no reconoce la existencia de una legalidad preexistente; ya que por el contrario este es el promotor y engendrador de los entes encargados de legislar. En verdad, se trata de un poder transformador que no reconoce ni acepta la continuidad en forma alguna, del orden institucional precedente. Asimismo, plantea que en el caso del poder constituyente derivado, cuando se ha llevado a cabo una reforma de conformidad con el procedimiento establecido en la propia Constitución, no cabe aceptar la responsabilidad del Estado, ni habría norma superior en que fundarla, salvo que la propia reforma así lo estableciera para sus consecuencias prácticas en la ciudadanía.

En la hipótesis de una reforma constitucional violatoria de la Constitución, cabría dos posibilidades. Aplicar la fórmula establecida por el propio texto supra y en caso de carencia la instituida por el órgano de control de la constitucionalidad. vía una sentencia. En relación con el mismo tema, aparece también el concepto de que nadie tiene derechos irrevocablemente adquiridos frente a una norma de orden público.

En ese sentido, al tener los preceptos constitucionales un carácter de normas de orden público -ya que rigen la organización del Estado y su actividad destinada a regular las bases fundamentales del funcionamiento y conservación del grupo socialsu existencia per se no da lugar al surgimiento de responsabilidades especiales respecto a particulares, salvo que así lo dispusiera expresamente la propia norma constitucional.

En cambio, Miguel MarienhofP ${ }^{7}$ ha señalado que:

"(...) la responsabilidad del Estado puede derivar de una reforma constitucional, si implicase un agravio preciso y concreto a un ciudadano, cuya facultad legal para hacer o no hacer le es retirada $(\ldots)^{\prime \prime}$.

Así, „o toda reforma constitucional determina una responsabilidad para el Estado, ya que esta solo tiene lugar en tanto el objeto o contenido de aquella implique un acto que afecte concretamente la esfera jurídica del ciudadano.

Según esta tesis, la reforma de la Constitución no puede despojar -es decir, privar sin indemnización- a parte de la ciudadanía, de los derechos que la Constitución originaria le atribuyó.

Así, entiende que el Estado tiene, en principio, el deber jurídico de respetar las consecuencias de lo originariamente concebido y establecido como regla básica de convivencia. Expone que es dable suponer también, que toda reforma constitucional tiene por objeto satisfacer requerimientos de interés general o de interés público, de donde se derivaría la obvia necesidad de resarcir por los daños que los ciudadanos sufran en semejantes condiciones.

María Graciela Reiriz [Responsabilidad del Estado. Buenos Aires: Eudeba. 1986], por el contrario, plantea que los ciudadanos carecen de atribución alguna para responsabilizar al Estado por las consecuencias de una reforma constitucional que 
suprima derechos que la ley básica de la República les ha concedido. La tesis parte del supuesto de que el órgano constituyente no es, en esencia, un órgano del Estado, por "cuanto se encuentra por encima de él; más aún, es su fuente de creación".

Por ende, la responsabilidad por la decisión le cabe exclusivamente al pueblo a través del órgano constituyente; en suma, la imputación de la responsabilidad recae en el pueblo mismo. Esta materia tiene singular importancia para nuestra Constitución si partimos de la posibilidad de que mediante una reforma constitucional:

Se enerve la garantía de la libertad sindical prescrita en el artículo $28^{\circ}$ inc. 1.

Se retire la facultad de los trabajadores a participar en las utilidades de la empresa, prescrita en el artículo $29^{\circ}$.

Se suprima el pluralismo económico definido en el artículo $60^{\circ}$.

Sed esconozca la libre competencia defendida en el artículo $61^{\circ}$.

La experiencia histórica indica que el Estado surgido de un poder constituyente originario refundacional, en múltiples oportunidades se ha negado a reparar el daño causado a los titulares de derechos extintos. A guisa de ejemplo, aparecen los casos de la confiscación de bienes de la casa de Saboya -familia reinante en Italia de 1860 a 1946- establecida por la Constitución italiana de 1947; y la abolición de la propiedad de la tierra y la nacionalización de la banca consignada en la Constitución de la URSS de 1918.'

Empero, también pueden citarse medidas reparatorias residuales como la prevista en la Constitución nicaragüense de 1987, en donde la privación del derecho de propiedad por razones de reforma agraria se hace con sujeción a un pago indemnizatorio. 